\title{
Sediment transport in runoff on rugous soil surface submitted to simulated rainfall
}

\author{
Ildegardis Bertol*; Wilson Antonio Zoldan Junior¹; Antonio Paz González²; Fabrício \\ Tondello Barbosa ${ }^{1}$; Romeu de Suza Werner ${ }^{1}$ \\ ${ }^{1}$ UDESC - Depto. de Solos e Recursos Naturais - C.P. 281 - 88520-000 - Lages, SC - Brasil. \\ ${ }^{2}$ Universidade da Coruña - Edafologia y Química Agrícola - 15071 - La Coruña - Espanha. \\ *Corresponding author <a2ib@cav.udesc.br>
}

\begin{abstract}
Soil management influences water erosion and sediment size in runoff. With the objective of quantifying sediments in runoff and their relation to runoff velocity ( $R v)$, random roughness (RR), and Ir index, this experiment was carried out from 2003 to 2006, on a typical Hapludox with the following soil management systems submitted to chiseling: i) bare soil with plowing + two disking tillage (BSC); ii) plowing + two disking tillage (CTC); iii) no tillage with crop residues burned (BNTC); and iv) traditional notillage (TNTC). CTC, BNTC and TNTC treatments were cultivated with crop rotation and the BSC treatment was not cultivated. Five simulated rainfall tests were applied, with intensity of $64 \mathrm{~mm} \mathrm{~h}^{-1}$ and duration of 20 , $30,40,50$ and $60 \mathrm{~min}$. RR was influenced by the residual effect of soil management and by simulated rainfall, and affected the $\mathrm{Rv}$ in the three initial rainfall tests. Sediments carried by runoff were influenced by soil management and by simulated rainfall. Most of the sediments were in the size range from 0.5 to $>2 \mathrm{~mm}$, with a higher quantity of fine sediment in BNTC and TNTC treatments than in the other treatments. The $\mathrm{D}_{50}$ index of sediments changed with soil management system and with rainfall tests, decreasing with the increase of the RR and increasing with the increment of $\mathrm{Rv}$ and Ir index.

Key words: water erosion, chiseling, no-till, sediment $\mathrm{D}_{50}$ index
\end{abstract}

\section{Sedimentos transportados na enxurrada em superfície de solo rugosa submetida à chuva simulada}

\begin{abstract}
RESUMO: O manejo do solo influencia a erosão hídrica e o tamanho de sedimentos na enxurrada. Com o objetivo de quantificar os sedimentos na enxurrada e relacioná-los com sua velocidade (Ve), com a rugosidade (RR) e com o índice Ir, conduziu-se este estudo entre 2003 e 2006, em um Nitossolo, sob sistemas de manejo do solo submetidos a uma escarificação: i) solo descoberto com aração e duas gradagens (SCE); ii) aração e duas gradagens (PCE); iii) semeadura direta em solo nunca preparado e com resíduos queimados (SQE); e iv) semeadura direta tradicional (STE). Os tratamentos PCE, SQE e STE foram cultivados com rotação de culturas e o SCE não foi cultivado. Foram aplicados cinco testes de chuva simulada, com intensidade constante de $64 \mathrm{~mm} \mathrm{~h}^{-1}$ e durações de 20, 30, 40, 50 e 60 minutos cada um. A RR foi influenciada pelo efeito residual do manejo do solo e pelas chuvas simuladas e afetou a Ve nos três testes iniciais de chuva. Os sedimentos transportados pela enxurrada foram influenciados pelo manejo do solo e pelas chuvas simuladas; tais sedimentos ocorreram em maior quantidade no tamanho entre 0,5 e $>2 \mathrm{~mm}$ do que nos tamanhos menores, com maior quantidade de sedimentos menores nos tratamentos SQE e STE do que nos demais tratamentos. O índice $\mathrm{D}_{50}$ dos sedimentos variou com o manejo do solo e com os testes de chuva, diminuindo com o incremento de RR e aumentando com o incremento de Ve de Ir.

Palavras-chave: erosão hídrica, escarificação, semeadura direta, índice $\mathrm{D}_{50}$ dos sedimentos
\end{abstract}

\section{Introduction}

It is important to know the quantity and sediment size distribution eroded by runoff, as well as their relation to soil surface roughness and runoff parameters, in order to select soil management systems and soil conservative practices. Long-term soil cultivation with intensive mechanical mobilization increases the amount of disaggregated sediments and their disposal for runoff, while a reduced mobilization decreases the amount of those sediments (Bertol et al., 2008; Cogo et al., 1983; Engel et al., 2009; Leite et al., 2004; Sadeghi et al., 2007).
Management practices applied to a soil over a time period can affect some of its physical properties which can be degraded due to the use of agricultural mechanization (Tormena et al., 2008), affecting runoff velocity and water erosion (Bertol et al., 1997; Cogo et al., 1983). Thus, each management practice causes additional effects on this surface roughness, especially related to mechanical till (Zoldan Júnior et al., 2008). Soil management with plowing and disking result in degradation of the soil structure (Amado et al., 2007). On the other hand, with no-tillage, the soil can have a better physical condition on its surface layer, due to less mechanical till, increasing soil consolidation, and maintaining its

Sci. Agric. (Piracicaba, Braz.), v.67, n.5, p.591-597, September/October 2010 
cover of crop residue, which adds organic matter to the soil surface (Bertol et al., 2004). The resultant conditions of those management practices can modify the soil surface, especially in relation to roughness and quantity and size of desegregated sediments (Bertol et al., 2008; Panuska et al., 2008; Zoldan Júnior et al., 2008). These conditions affect water erosion differently (Bertol et al., 2008; Sadeghi et al., 2007), and its potential to transport sediments (Bertol et al., 1997; Engel et al., 2009).

The roughness stability also differs when the soil is submitted to a till practice and of soils cropped for a long period of time influence the quantity and size of sediments transported by runoff. Chiseling is an important soil till operation to increase soil surface roughness (Bertol et al., 2008; Cogo et al., 1983). Thus, this research quantified sediments transported in runoff under different soil management systems after six and half years, and studied the effect of chisel till operations on the surface soil and runoff characteristics.

\section{Material and Methods}

This research was carried out from 2003 to 2006 in Santa Catarina State, Brazil, on a site located at latitude $28^{\circ} 56^{\prime} \mathrm{S}$, longitude $51^{\circ} 09^{\prime} \mathrm{W}$. The climate is humid subtropical (Cfb) according to Köppen's classification; the soil a clayey loamy Hapludox, with $680 \mathrm{~g} \mathrm{~kg}^{-1}$ of clay, $210 \mathrm{~g} \mathrm{~kg}^{-1}$ of sand, $110 \mathrm{~g} \mathrm{~kg}^{-1}$ of silt, $2.8 \mathrm{~g} \mathrm{~cm}^{-3}$ of particle density and $32 \mathrm{~g} \mathrm{~kg}^{-1}$ of total organic carbon in the $0-0.2$ $\mathrm{m}$ soil layer (Zoldan Júnior et al., 2008).

The experimental unit was made up of plots, with $3.5 \mathrm{~m}$ wide and $11 \mathrm{~m}$ long installed up-and-down the slope. The plots were framed by galvanized sheets $(0.2$ $\mathrm{m}$ high) put $0.1 \mathrm{~m}$ into the soil. A runoff-collector gutter was placed at the lower boundary, which was connected by a tube that, after collect, canalized the runoff to be collection $6 \mathrm{~m}$ below the plot. The slope of the plots ranged from 0.13 to $0.21 \mathrm{~m} \mathrm{~m}^{-1}$.

The treatments, with two replicates, consisted of four soil management systems conducted for 5.5 years as following - i) bare soil with one plowing $(0.2 \mathrm{~m}$ depth) + two disking $(0.15 \mathrm{~m}$ depth) up-and-down the slope, twice a year with additional manual weeding and chiseling, in order to maintain soil surface weed free and with no crust throughout time, without crop (BS); ii) one plowing $(0.2 \mathrm{~m})+$ two disking $(0.15 \mathrm{~m})$ twice a year; the residues were incorporated into the soil and oat residues were maintained on the soil surface for the last 6 months (CT); iii) no-till on natural grassland area cultivated without soil till; residues were burned (NTB); and iv) continuous no-till after one conventional till at the establishment of the area named traditional no till; residues were maintained on the soil surface (TNT). Crop sequences of oat (Avena sativa), soybean (Glycine max), vetch (Vicia sativa), maize (Zea mays), oat, bean (Phaseollus vulgaris), fodder radish (Raphanus sativus), soybean, vetch, maize and oats were cultivated in CT, NTB and TNT treatments for 5.5 years. Oat residues were removed from the plots in the CT and TNT treatments and were burned in NTB treatment in January, 2006, prior to soil chiseling. One day after these operations, a chiseling was carried out on all treatments, when soil had good friability, and adequate water content. The chisel plough equipment had 13 tines $(0.25 \mathrm{~m}$ between each other), working $0.18 \mathrm{~m}$ into the soil. So, the previous BS, CT, NTB and TNT treatments were then named BSC, CTC, NTBC and TNTC, respectively.

A rotating-boom rainfall simulator was used in this research, operating at a constant rainfall intensity and covering simultaneously two plots, $3.5 \mathrm{~m}$ apart from each other. The rotating-boom operated on $3.5 \mathrm{~m}$ interval between the two plots, according to Swanson's recommendation (1965). The following rainfall simulation tests (with $64 \mathrm{~mm} \mathrm{~h}^{-1}$ intensity) were applied: - test 1 , January 12, 2006, for 20 minutes, one day after the soil chiseling; test 2, for 30 minutes, applied four days after test 1 ; test 3 , for 40 minutes, applied seven days after test 2 ; test 4 , for 50 minutes, applied nine days after test 3 ; and test 5 , for 60 minutes, applied six days after test 4 . The rainfall intensity of $64 \mathrm{~mm} \mathrm{~h}^{-1}$ is a critical intensity for this region; consequently, it is recommended for a soil water erosion study. Rainfall simulated volume and erosivity are shown in Table 1 . The natural rainfall during the experiment period was of $57 \mathrm{~mm}$ between tests 2 and 3, $21 \mathrm{~mm}$ between tests 3 and 4 , and $30 \mathrm{~mm}$ between tests 4 and 5 .

The soil surface roughness was evaluated immediately before each simulated rainfall test, using equipment with 20 aluminum sticks of $600 \mathrm{~mm}$ length, diameter of $8 \mathrm{~mm}$, disposed $30 \mathrm{~mm}$ from each other along a level support, in which a digital camera was connected $1.80 \mathrm{~m}$ from the sticks (more details in Zoldan Júnior et al., 2008). Roughness index was calculated by the standard deviation of soil surface height data with no transformation and no elimination of extreme values, according to the method proposed by Kamphorst et al. (2000). Runoff velocity was measured using a $2 \%$ methylene blue-based solution applied on the surface flow, at $6 \mathrm{~m}$ intervals in the intermediate position of each experimental plot.

Sediments transported in the runoff were collected 10 min before the end of each simulated rainfall, separating into different sizes using, a set of sieves with 2; 1; 0.5 and $0.25 \mathrm{~mm}$ installed inside a $2.5 \mathrm{~L}$ container, collecting the flow for $30 \mathrm{~s}$ until it was completely full. In the laboratory, the collected material was passed through an additional set of sieves with $0.125 ; 0.053$, and $0.038 \mathrm{~mm}$, to separate the following sediment size classes: $>2 ; 1-2 ; 0.5-1 ; 0.25-0.5 ; 0.125-0.25 ; 0.053$ $0.125 ; 0.038-0.053$; and $<0.038 \mathrm{~mm}$, according to procedure described by Bertol et al. (2006). After wards, the $\mathrm{D}_{50}$ index of sediments was calculated using the procedure adopted by Gilley et al. (1987).

An index of soil resistance to sediment transport (Ir) was established, from the product of the soil surface random roughness and runoff velocity values. The sediment transported by runoff is strongly influenced by soil sur- 
face roughness and runoff velocity (Bertol et al., 2008; Cogo et al., 1983), among other factors, which justifies the formulation of that index.

The effect of the treatments was tested through variance analysis, considering a split-plot model, using treatments as a main factor and time as a secondary factor. The differences between means were compared by $\mathrm{T}$ test $(p<0.05)$. The $\mathrm{D}_{50}$ index of sediments was related to the Ir index, by a $y=a x^{b}$ model, and the $D_{50}$ index of sediments was related to the soil surface random roughness and to the runoff velocity, by a $y=a+b x$ model.

\section{Results and Discussion}

Soil surface roughness and runoff velocity

The soil management systems in cropped treatments (TNTC, BNTC and CTC) had surface roughness val- ues $61 \%$ higher than the bare soil and the treatment without crop systems (BSC), on the average of treatments and rainfall tests (Table 2). This result demonstrates the importance of the soil crop to conserve physical properties related to soil aggregation, independent of the soil management system. A negative correlation between soil surface random roughness decay and water aggregate stability (MWD and GMD) in the 0-0.1 m layer of an Inceptisol was found by Bertol et al. (2006). Furthermore, physically-desegregated soils had lower surface roughness than those better structured, as observed by Zoldan Júnior et al. (2008).

Although TNTC treatment showed a similar surface roughness in relation to CTC treatment $(p<0.05$ - Table $2)$, there was an addition of $17 \%$ in TNTC roughness $(p<0.2)$, in comparison with the CTC treatment, on the average of the rainfall tests. This is an important in-

Table 1 - Simulated rainfall volume and erosivity $\left(\mathrm{EI}_{30}\right)$, applied after the chiseling operation.

\begin{tabular}{|c|c|c|c|c|c|c|}
\hline Treatment & Test 1 & Test 2 & Test 3 & Test 4 & Test 5 & Total \\
\hline & \multicolumn{6}{|c|}{ - Volume, $\mathrm{mm}$ - } \\
\hline BSC & 20 & 39 & 46 & 59 & 68 & 232 \\
\hline CTC & 21 & 41 & 46 & 60 & 78 & 246 \\
\hline BNTC & 22 & 38 & 45 & 58 & 69 & 232 \\
\hline \multirow[t]{2}{*}{ TNTC } & 22 & 38 & 49 & 58 & 73 & 240 \\
\hline & \multicolumn{6}{|c|}{$\mathrm{EI}_{30}, \mathrm{MJ} \mathrm{mm} \mathrm{ha}^{-1} \mathrm{~h}^{-1}$} \\
\hline $\mathrm{BSC}$ & 256 & 621 & 669 & 868 & 950 & 3,364 \\
\hline CTC & 265 & 686 & 648 & 917 & 1.273 & 3,789 \\
\hline BNTC & 294 & 612 & 624 & 854 & 982 & 3,366 \\
\hline TNTC & 302 & 609 & 747 & 849 & 1.097 & 3,604 \\
\hline
\end{tabular}

BSC: bare soil with plowing + double disking tillage without crop soil; CTC: plowing + double disking tillage; BNTC: no-tillage in a never tilled soil and with residues burned; TNTC: traditional no-tillage (CTC, BNTC and TNTC, tillage with crop soil).

Table 2 - Soil surface random roughness determined immediately before each simulated rainfall, and runoff velocity determined during the simulated rainfall after the chiseling operation.

\begin{tabular}{|c|c|c|c|c|c|c|c|}
\hline Treatment & Test 1 & Test 2 & Test 3 & Test 4 & Test 5 & Mean & $\mathrm{CV}$ \\
\hline & \multicolumn{6}{|c|}{ Roughness, mm - } & $\%$ \\
\hline BSC & $8.19 \mathrm{Ba}$ & $7.55 \mathrm{Ba}$ & $5.11 \mathrm{Ba}$ & $5.63 \mathrm{Aa}$ & $9.56 \mathrm{Aa}$ & $7.22 \mathrm{~B}$ & 24.76 \\
\hline CTC & $14.94 \mathrm{Aa}$ & $12.02 \mathrm{Aab}$ & $9.61 \mathrm{ABab}$ & $9.40 \mathrm{Aab}$ & $8.46 \mathrm{Ab}$ & $10.78 \mathrm{~A}$ & 20.42 \\
\hline BNTC & $15.07 \mathrm{Aa}$ & $13.89 \mathrm{Aa}$ & $10.65 \mathrm{ABb}$ & $9.49 \mathrm{Ab}$ & $8.70 \mathrm{Ab}$ & $11.56 \mathrm{~A}$ & 10.87 \\
\hline TNTC & $17.55 \mathrm{Aa}$ & $12.91 \mathrm{Aab}$ & $11.89 \mathrm{Aab}$ & $11.19 \mathrm{Aab}$ & $9.40 \mathrm{Ab}$ & $12.60 \mathrm{~A}$ & 20.31 \\
\hline \multirow[t]{2}{*}{ CV (\%) } & 12.60 & 13.27 & 21.95 & 27.00 & 24.41 & - & - \\
\hline & \multicolumn{7}{|c|}{ Runoff velocity, $\mathrm{m} \mathrm{s}^{-1}$} \\
\hline BSC & $\mathrm{OAc}$ & $0 \mathrm{Ac}$ & $0.25 \mathrm{Ab}$ & $0.26 \mathrm{Ab}$ & $0.31 \mathrm{Aa}$ & $0.27 \mathrm{~A}$ & 5.45 \\
\hline CTC & $0 \mathrm{Ad}$ & $0 \mathrm{Ad}$ & $0.17 \mathrm{Bc}$ & $0.27 \mathrm{Ab}$ & $0.33 \mathrm{Aa}$ & $0.26 \mathrm{~A}$ & 10.61 \\
\hline BNTC & $0 \mathrm{Ad}$ & $O \mathrm{Ad}$ & $0.12 \mathrm{Cc}$ & $0.14 \mathrm{Bb}$ & $0.19 \mathrm{Ba}$ & $0.15 \mathrm{~B}$ & 6.30 \\
\hline TNTC & $0 \mathrm{Ad}$ & $0 \mathrm{Ad}$ & $0.05 \mathrm{Dc}$ & $0.06 \mathrm{Cb}$ & $0.10 \mathrm{Ca}$ & $0.07 \mathrm{C}$ & 2.61 \\
\hline CV (\%) & 0 & 0 & 5.97 & 7.35 & 6.30 & - & - \\
\hline
\end{tabular}

BSC: bare soil with plowing + double disking tillage without crop soil; CTC: plowing + double disking tillage; BNTC: no-tillage in a never tilled soil and with residues burned; TNTC: traditional no-tillage (CTC, BNTC and TNTC, tillage with crop soil). Means followed by the same letters not differ (T test, $p<0.05)$. Upper case letters in column and lower case letters in line. CV: coefficient of variation. 
crease in the surface water storage capacity in no-tillage in relation to conventional tillage, when both are scarified by a chisel operation. Probably, that difference $(p<0.2)$ was due to a better soil structure in TNTC treatment than in CTC treatment. Soil surface roughness decreased $44 \%$ from the first to the fifth simulated rainfall test, on the average of the cropped treatments, and $38 \%$ in the no cropped treatment. The low reduction in roughness values observed in the cropped treatments in relation to bare soil demonstrates the importance of soil cultivation to conserve soil physical properties. A rapid decrease in random roughness in the no cropped soil during rainfalls was also verified by PazFerreiro et al. (2008) and Zoldan Júnior et al. (2008), while, low reduction in roughness in a cropped soil was verified by Bertol et al. (2006).

Runoff velocity was evaluated only after the third test because, before that, water infiltration capacity was higher than the simulated rainfall height. In TNTC treatment the runoff velocity was $27 \%$ of that verified in CTC treatment and, in relation to BNTC treatment, it was $47 \%$, on the average of rainfall tests (Table 2). Thus, TNTC treatment was more efficient in increasing the surface roughness in comparison to CTC $(p<0.2)$. Moreover, it was also more efficient in reducing runoff velocity, as also verified by Bertol et al. (2006). The soil surface roughness is an important soil property which influences runoff velocity, soil water infiltration and runoff quantity. Runoff velocity increased $59 \%$ in CTC treatment and $20 \%$ in TNTC treatment, from test 3 to test 4 (Table 2), explained because of the better soil physical quality in TNTC treatment. When comparing TNTC and BNTC treatments in this period, runoff velocity increased less in BNTC (17\%) than in TNTC $(20 \%)$, which demonstrates lower degradation of the soil surface despite one residue removal by burning, but with no tillage at the establishment the experiment, as verified by Bertol et al. (2006).

\section{Sediments transported by runoff}

Sediment transported by runoff varied between treatments, sediment sizes and rainfall tests, with a tendency of increasing the quantity of coarse-size sediments and decreasing quantity of fine-size sediments (Table 3). This tendency is normal and can be justified due to the chiseling operation, considered as minimal soil tillage, performed in all treatments, causing the formation of coarse sediments, predominantly. Expressive variations in sediment quantity and sediment size distribution from runoff as a function of soil management systems were found by Bertol et al. (2006), Bertol et al. (2008) and Panuska et al. (2008).

Sediment size from 0.038 to $0.053 \mathrm{~mm}$ occurred in low quantity ( $0.4 \mathrm{~g}$ in BNTC and TNTC treatments), while sediment size from 1 to $2 \mathrm{~mm}$ showed the highest quantity (51.2 $\mathrm{g}$ in BSC treatment) (Table 3), on the average of the rainfall tests. Soil mechanical mobilization with plowing and disking with no crop in BSC treatment, and soil no-till and the presence of crops in BNTC and
TNTC treatments justify these results. This demonstrates the importance of minimum soil mobilization to reduce the quantity of sediments available for transport by runoff, since, fine-size sediments are more easily transported by runoff than coarse-size sediments. Similar results were found by Bertol et al. (2006), Cogo et al. (1983) and Panuska et al. (2008).

Comparing CTC and TNTC treatments, in the CTC, $93 \%$ of the total sediment size was from 0.5 to $>$ $2 \mathrm{~mm}$, while, in TNTC, this size class reached $80 \%$ of total sediment, on the average of the rainfall tests (Table 3). On the other hand, size from $<0.038$ to $0.125 \mathrm{~mm}$ accounted for only $3.3 \%$ of the sediments in CTC treatment and, in TNTC, 9.68\%. Clearly, these results demonstrate that no-till had finer sediments in comparison to plowing plus disking treatment (with intense soil mechanical mobilization), as also reported by Bertol et al. (2006), Cogo et al. (1983) and Leite et al. (2004). That fact can be related to off site results in environmental contamination, mainly on water resources, because fine sediments are more efficient in adsorbing and transporting chemical products in runoff.

In sediment sizes from 0.5 to $>2 \mathrm{~mm}$, the amount of sediments transported by runoff increased from rainfall test 4 to test 5 . Conversely, such amount decreased in size from $<0.038$ to $0.125 \mathrm{~mm}$ (Table 3). In coarse sediments the values were $87 \%$ of the total transported in test 4 and $90 \%$ in test 5 , while in fine sediments (on the average of treatments) the amounts were only $8 \%$ and $7 \%$ of total transported sediments in the respective tests. In CTC treatment, coarse sediments represent $92 \%$ of the total transported in test 4 and $94 \%$ in test 5 . Fine sediments, reach only $3.1 \%$ of the total transported in test 4 and $2.5 \%$ in test 5 . In the TNTC treatment, on the other hand, considering coarse sediments, these amounts were $77 \%$ in test 4 and $87 \%$ in test 5 , while, in fine sediments, the values were of $11 \%$ in test 4 and $7 \%$ in test 5 . Those tendencies are normal, considering that the chiseling mechanical operation occurred in all treatments, partially revolved the soil, and produced available sediments to be transported. Coarse sediments generated by soil till operation were transported, mainly in rainfall test 4 , and, in test 5 , these coarse sediments were probably produced mainly by rainfall energy and water flow on the rills, according to $\mathrm{Lu}$ et al. (1989).

The total quantity of transported sediments in the runoff was relatively high, considering the short-term sampling collection (30 s), with an expressive variation among treatments and sediment sizes (Table 3 ). The TNTC treatment was the most efficient, reducing $82 \%$ of the quantity of sediments in relation to BSC and, $45 \%$ in relation to CTC treatment, on the average of the rainfall tests and sediment sizes. These data confirmed that the losses of the fine sediments were higher in the notill than in the conventional till system, as reported by Bertol et al. (2006), Cogo et al. (1983) and Leite et al. (2004). From that, it is possible to infer a higher potential for environmental chemical contamination in off-site 
Table 3 - Sediments size distribution presents in runoff, in different treatments (Treat.) after chiseling operation.

\begin{tabular}{|c|c|c|c|c|c|c|c|c|c|c|}
\hline \multirow{2}{*}{ Treat } & \multicolumn{8}{|c|}{ Sediments size (mm) } & \multirow{2}{*}{ Total } & \multirow{2}{*}{$\mathrm{CV}$} \\
\hline & $>2$ & $1-2$ & $0.5-1$ & $0.25-0.5$ & $0.125-0.25$ & $0.053-0.125$ & $0.038-0.053$ & 0.038 & & \\
\hline & \multicolumn{8}{|c|}{ } & & $\%$ \\
\hline \multicolumn{11}{|c|}{ Test 3} \\
\hline BSC & $37.5 \mathrm{Ab}$ & $56.8 \mathrm{Aa}$ & $56.7 \mathrm{Aa}$ & $15.2 \mathrm{Ac}$ & $6.8 \mathrm{Ad}$ & $2.1 \mathrm{Ae}$ & $1.0 \mathrm{Ae}$ & $2.8 \mathrm{Ae}$ & $179 \mathrm{~A}$ & 5.09 \\
\hline CTC & $0.9 \mathrm{Cb}$ & $1.6 \mathrm{Cd}$ & $2.2 \mathrm{Ca}$ & $1.3 \mathrm{Cc}$ & $0.5 \mathrm{Ce}$ & $0.2 \mathrm{Cf}$ & $0.1 \mathrm{Cf}$ & $0.5 \mathrm{Ce}$ & $7.2 \mathrm{C}$ & 8.78 \\
\hline BNTC & $5.3 \mathrm{Bb}$ & $5.6 \mathrm{Bb}$ & $11.7 \mathrm{Ba}$ & $6.5 \mathrm{Bb}$ & $1.3 \mathrm{Cc}$ & $0.9 \mathrm{Bc}$ & $0.5 \mathrm{Bc}$ & $1.3 \mathrm{Bc}$ & $33.0 \mathrm{~B}$ & 16.40 \\
\hline TNTC & $0.6 \mathrm{Ce}$ & $1.3 \mathrm{Cc}$ & $1.8 \mathrm{Cb}$ & $1.9 \mathrm{Cb}$ & $2.5 \mathrm{Ba}$ & $0.9 \mathrm{Bd}$ & $0.3 \mathrm{Cf}$ & $0.5 \mathrm{Ce}$ & $9.6 \mathrm{C}$ & 6.28 \\
\hline CV (\%) & 9.94 & 4.20 & 5.36 & 14.10 & 12.98 & 3.49 & 17.09 & 4.95 & 4.87 & - \\
\hline \multicolumn{11}{|c|}{ Test 4} \\
\hline BSC & $14.5 \mathrm{Ab}$ & $28.1 \mathrm{Aa}$ & $15.8 \mathrm{Ab}$ & $13.6 \mathrm{Ab}$ & $4.5 \mathrm{Ac}$ & $1.7 \mathrm{Ac}$ & $0.9 \mathrm{Ac}$ & $2.4 \mathrm{Ac}$ & $81.2 \mathrm{~A}$ & 17.53 \\
\hline CTC & 10.5 Bab & $11.1 \mathrm{Ba}$ & $9.8 \mathrm{Bb}$ & $3.7 \mathrm{Cc}$ & $2.0 \mathrm{Cd}$ & $0.5 \mathrm{Ce}$ & $0.2 \mathrm{Ce}$ & $0.5 \mathrm{Ce}$ & $38.2 \mathrm{~B}$ & 6.91 \\
\hline BNTC & $7.1 \mathrm{Cb}$ & $5.3 \mathrm{BCc}$ & $12.5 \mathrm{ABa}$ & $5.8 \mathrm{Bc}$ & $3.2 \mathrm{Bd}$ & $1.1 \mathrm{Be}$ & $0.5 \mathrm{Be}$ & $0.6 \mathrm{BCe}$ & $35.9 \mathrm{~B}$ & 8.46 \\
\hline TNTC & $3.5 \mathrm{Dc}$ & $4.1 \mathrm{Cb}$ & $5.8 \mathrm{Ca}$ & $3.2 \mathrm{Ccd}$ & $2.8 \mathrm{Bd}$ & $1.0 \mathrm{Be}$ & $0.5 \mathrm{Bf}$ & 0.9 Bef & $21.5 \mathrm{C}$ & 6.58 \\
\hline CV (\%) & 6.92 & 17.78 & 11.72 & 5.38 & 8.27 & 8.25 & 12.56 & 10.40 & 4.27 & - \\
\hline \multicolumn{11}{|c|}{ Test 5} \\
\hline BSC & $14.6 \mathrm{Bc}$ & $68.7 \mathrm{Aa}$ & $42.9 \mathrm{Ab}$ & 14.3 Ac & $6.5 \mathrm{Ad}$ & 4.0 Ade & $1.4 \mathrm{Ae}$ & 5.8 Ade & $158.0 \mathrm{~A}$ & 9.68 \\
\hline CTC & $25.2 \mathrm{Ab}$ & $19.2 \mathrm{Bc}$ & $28.8 \mathrm{Ba}$ & $12.0 \mathrm{Bd}$ & $3.3 \mathrm{BCe}$ & $1.0 \mathrm{Cf}$ & $0.5 \mathrm{Bf}$ & $0.8 \mathrm{Bf}$ & $90.6 \mathrm{~B}$ & 6.29 \\
\hline BNTC & $9.1 \mathrm{Cc}$ & $9.0 \mathrm{Cc}$ & $14.4 \mathrm{Ca}$ & $11.7 \mathrm{Bb}$ & $4.1 \mathrm{Bd}$ & $1.5 \mathrm{Be}$ & $0.2 \mathrm{Ce}$ & $0.8 \mathrm{Be}$ & $50.7 \mathrm{C}$ & 9.65 \\
\hline TNTC & $12.0 \mathrm{Ba}$ & $9.9 \mathrm{Cc}$ & $10.9 \mathrm{Cb}$ & $4.9 \mathrm{Cd}$ & $2.9 \mathrm{Ce}$ & $1.3 \mathrm{BCf}$ & $0.3 \mathrm{Cg}$ & $1.3 \mathrm{Bf}$ & $43.3 \mathrm{C}$ & 6.75 \\
\hline CV (\%) & 6.43 & 2.13 & 11.20 & 5.40 & 8.03 & 7.79 & 8.70 & 21.69 & 3.58 & - \\
\hline \multicolumn{11}{|c|}{ Mean of tests } \\
\hline BSC & $22.2 \mathrm{Ac}$ & $51.2 \mathrm{Aa}$ & $38.5 \mathrm{Ab}$ & $14.4 \mathrm{Ad}$ & $5.9 \mathrm{Ae}$ & $2.6 \mathrm{Af}$ & $1.1 \mathrm{Ag}$ & $3.6 \mathrm{Af}$ & $139 \mathrm{~A}$ & 3.61 \\
\hline CTC & $12.2 \mathrm{Bb}$ & $10.7 \mathrm{Bc}$ & $13.6 \mathrm{Ba}$ & $5.7 \mathrm{Cd}$ & $1.9 \mathrm{Ce}$ & $0.6 \mathrm{Cf}$ & $0.3 \mathrm{Bf}$ & $0.6 \mathrm{Bf}$ & $45.4 \mathrm{~B}$ & 4.69 \\
\hline BNTC & $7.1 \mathrm{Cc}$ & $6.6 \mathrm{Cd}$ & $12.9 \mathrm{Ba}$ & $8.0 \mathrm{Bb}$ & $2.9 \mathrm{Be}$ & $1.2 \mathrm{Bf}$ & $0.4 \mathrm{Bg}$ & $0.9 \mathrm{Bf}$ & $39.9 \mathrm{C}$ & 3.72 \\
\hline TNTC & $5.4 \mathrm{Db}$ & $5.1 \mathrm{Dc}$ & $6.1 \mathrm{Ca}$ & $3.3 \mathrm{Dd}$ & $2.7 \mathrm{Be}$ & $1.1 \mathrm{Bf}$ & $0.4 \mathrm{Bg}$ & $0.9 \mathrm{Bf}$ & $24.8 \mathrm{D}$ & 3.95 \\
\hline CV (\%) & 3.24 & 2.52 & 3.51 & 5.89 & 4.37 & 4.58 & 11.95 & 14.14 & 1.16 & - \\
\hline
\end{tabular}

BSC: bare soil with plowing + double disking tillage crop without crop soil; CT: plowing + double disking tillage; BNTC: no-tillage in a never soil tilled and with residues burned; TNTC: traditional no-tillage (CTC, BNTC and TNTC, tillage with crop soil). Means followed by the same letters not differ (T test, $p<0.05$ ). Upper case letters in column and lower case letters in line. CV: coefficient of variation.

erosion impacts, is caused mainly by fine sediments from the no-till system.

The $\mathrm{D}_{50}$ index of the runoff transported sediments were different between the treatments in the three rainfall tests in which runoff occurred (Table 4), as verified by Bertol et al. (2006), Cogo et al. (1983) and Leite et al. (2004). In rainfall test 3 the $\mathrm{D}_{50}$ index was lower in TNTC than in the other treatments. Considering the average of the tests, $\mathrm{D}_{50}$ index in TNTC was $30 \%$ lower than in CTC treatment. The absence of soil mechanical till during several years in TNTC could explain why this index was lower than in the CTC treatment, in which soil till was routinely done with plowing and disking, although both treatments were cultivated and after, submitted to the same chiseling operation. In the TNTC treatment, the reduction caused in the $\mathrm{D}_{50}$ index was (on the average of the rainfall tests) $34 \%$ (in relation to the BSC treatment), due to the absence of a soil crop in BSC. Thus, the soil crop and mechanical till operation in- crease the quantity of coarse sediments in comparison with soil cultivated under no-till system.

Random roughness (RR) negatively influenced the $\mathrm{D}_{50}$ index of the sediments, as also verified by Bertol et al. (2006), Cogo et al. (1983) and Panuska et al. (2008); $75 \%$ of the $\mathrm{D}_{50}$ index was explained by $\mathrm{RR}$, on the average rainfall tests (Figure 1). Thus, rougher surfaces and/ or more stable roughness (as in CTC and TNTC treatments) can retain more sediments and, in general, the eroded sediments were coarser than on smoother surfaces and/or with fewer stable roughness (as in CTC and BSC treatment), as also verified by Darboux and Huang (2005). The main consequence of increasing superficial roughness is to decrease runoff velocity, volume and runoff transport energy (Bertol et al., 2006; Cogo et al., 1983 and $\mathrm{Lu}$ et al., 1989).

Runoff velocity ( $R v)$ positively influenced the $D_{50}$ index of sediments, as also reported by Bertol et al. (1997), Bertol et al. (2006), Cogo et al. (1983) and Leite et al. 
(2004); $61 \%$ of the $\mathrm{D}_{50}$ index was explained by $\mathrm{Rv}$, on the average simulated rainfall tests (Figure 2). Moreover, in treatments with more coarse sediments (CTC and BSC), runoff velocity was higher and, of course, transported more sediments than in treatments in which runoff was lower and transported finer-size sediments (BNTC and TNTC). Runoff velocity is the principal hydrological variable that influences the transport of sediments by soil water erosion.

The relation between $\mathrm{D}_{50}$ sediments index and the Ir index indicated that $63 \%$ of the $\mathrm{D}_{50}$ was explained by $\mathrm{Ir}$, on the average of the simulated rainfall tests (Figure 3). This still shows that the runoff velocity influences the
$\mathrm{D}_{50}$ index more than the surface roughness, when these variables are individually related to $\mathrm{D}_{50}$ index, as also verified by Bertol et al. (1997) and Cogo et al. (1983). This occurs because the $\mathrm{D}_{50}$ index increases with the increment of runoff velocity, and consequently, with the increase of Ir index, but it decreases with the roughness increase, as previously explained.

\section{Acknowledgements}

To Conselho Nacional de Desenvolvimento Científico e Tecnológico - CNPq for Research Scholarship and financial resources (Edital Universal 019/2004).

Table $4-\mathrm{D}_{50}$ index of the sediments transported by runoff, determined in applied simulated rainfall, after chiseling operation (means of two replicates).

\begin{tabular}{|c|c|c|c|c|c|c|c|}
\hline Treatment & Test 1 & Test 2 & Test 3 & Test 4 & Test 5 & Average & $\mathrm{CV}$ \\
\hline & \multicolumn{6}{|c|}{ 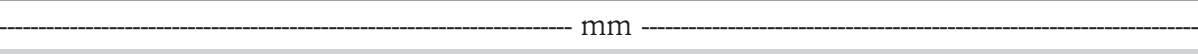 } & $\%$ \\
\hline BSC & 0 Ac & $0 \mathrm{Ac}$ & $0.535 \mathrm{Aa}$ & $0.515 \mathrm{Bb}$ & $0.520 \mathrm{Ab}$ & $0.523 \mathrm{~A}$ & 1.64 \\
\hline CTC & $0 \mathrm{Ad}$ & $0 \mathrm{Ad}$ & $0.375 \mathrm{Bc}$ & $0.605 \mathrm{Aa}$ & $0.495 \mathrm{Bb}$ & $0.492 B$ & 1.99 \\
\hline BNTC & $0 \mathrm{Ac}$ & 0 Ac & $0.375 \mathrm{Bb}$ & $0.395 \mathrm{Ca}$ & $0.380 \mathrm{Cb}$ & $0.383 \mathrm{D}$ & 1.80 \\
\hline TNTC & $0 \mathrm{Ad}$ & $0 \mathrm{Ad}$ & $0.170 \mathrm{Cc}$ & $0.370 \mathrm{Db}$ & $0.495 \mathrm{Ba}$ & $0.345 \mathrm{C}$ & 2.50 \\
\hline CV (\%) & 0 & 0 & 1.49 & 1.24 & 1.74 & - & - \\
\hline
\end{tabular}

BSC: bare soil with plowing + double disking tillage crop without crop soil; CTC: plowing + double disking tillage; BNTC: no-tillage in a never soil tilled and with residues burned; TNTC: traditional no-tillage (CTC, BNTC and TNTC, tillage with crop soil). Means followed by the same letters not differ ( $\mathrm{T}$ test, $p<0.05$ ). Upper case letters in column and lower case letters in line. CV: coefficient of variation.

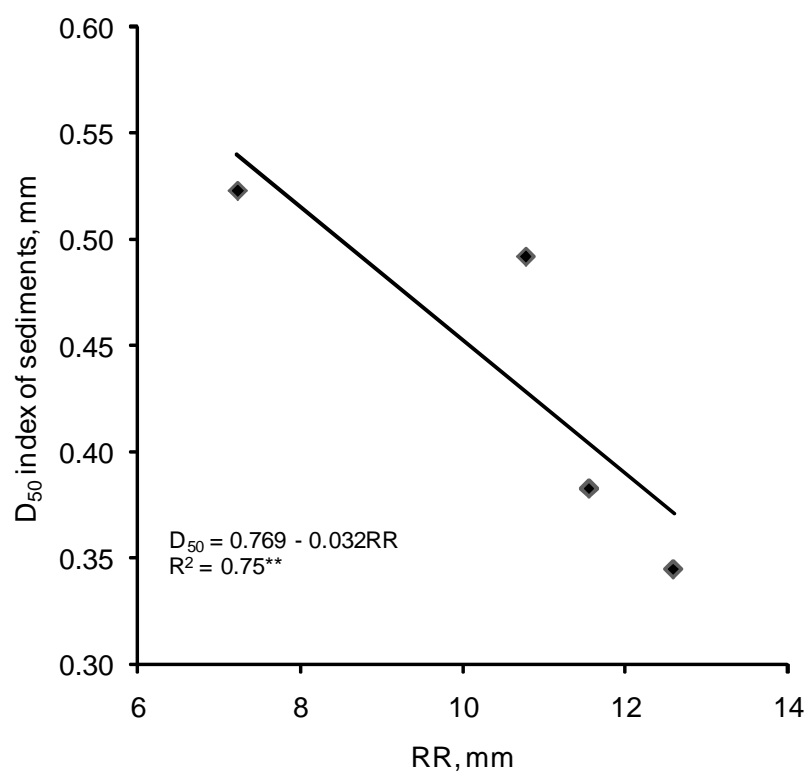

Figure 1 - Relationship between random roughness (RR) of the soil surface and $\mathrm{D}_{50}$ index of sediments transported by runoff, on the average of the simulated rainfall tests. BSC: bare soil with plowing + double disking tillage crop without crop soil; CTC: plowing + double disking tillage; BNTC: no-tillage in a never tilled soil and with residues burned; TNTC: traditional no-tillage (CTC, BNTC and TNTC, tillage with crop soil).

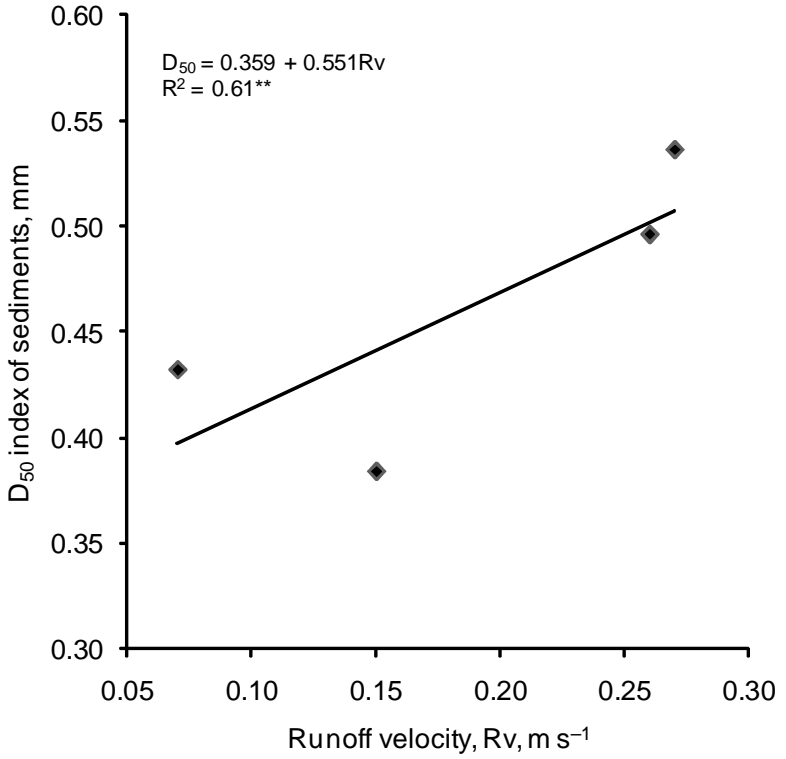

Figure 2 - Relationship between runoff velocity (Rv) and $\mathrm{D}_{50}$ index of the sediments transported by runoff, on the average of the simulate rainfall tests. BSC: bare soil with plowing + double disking tillage crop without crop soil; CTC: plowing + double disking tillage; BNTC: no-tillage in a never soil tilled and with residues burned; TNTC: traditional no-tillage (CTC, BNTC and TNTC, tillage with crop soil). 


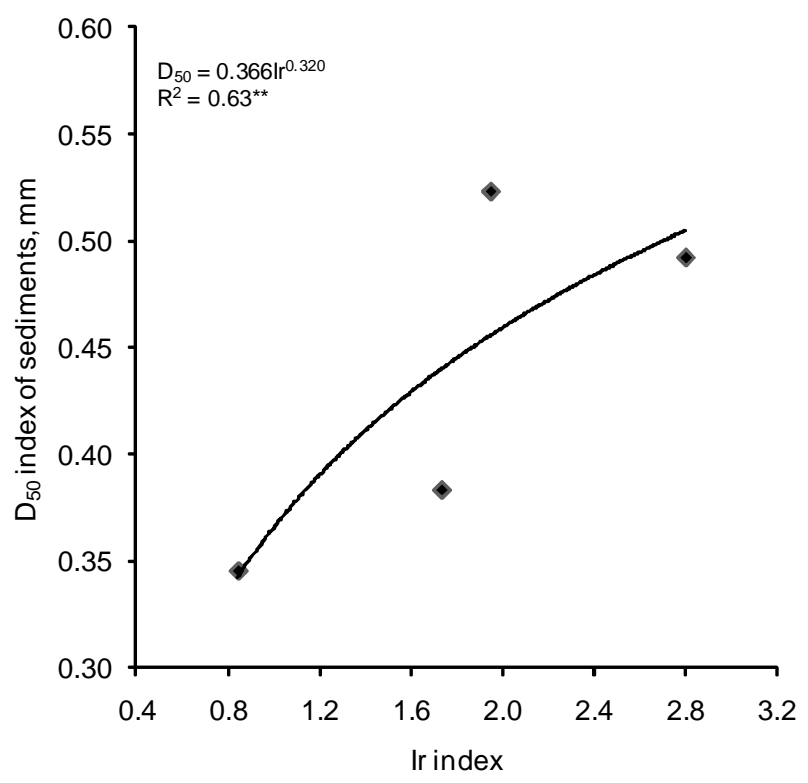

Figure 3 - Relationship between index ( $\mathrm{Ir}$ ) and $\mathrm{D}_{50}$ index of the sediments transported by runoff, on the average of the simulated rainfall tests. BSC: bare soil with plowing + double disking tillage crop without crop soil; CTC: plowing + double disking tillage; BNTC: no-tillage in a never tilled soil and with residues burned; TNTC: traditional no-tillage (CTC, BNTC and TNTC, tillage with crop soil).

\section{References}

Amado, T.J.C.; Conceição, P.C.; Bayer, C.; Eltz, F.L.F. 2007. Soil quality evaluated by "soil quality kit" in two long-term soil management experiments in Rio Grande do Sul State, Brazil. Revista Brasileira de Ciência do Solo 31: 109-121. (in Portuguese, with abstract in English).

Bertol, I.; Albuquerque, J.A.; Leite, D.; Amaral, A.J.; Zoldan Jr., W.A. 2004. Soil physical properties under conventional tillage and no-tillage, in crop rotation and succession after years six, to compared with natural pasture. Revista Brasileira de Ciência do Solo 28: 155-163. (in Portuguese, with abstract in English).

Bertol, I.; Amaral, A.J.; Vidal Vázquez, E.; Paz González, A.; Barbosa, F.T.; Brignoni, L.F. 2006. Relations of the soil surface roughness with the rainfall volume and with the aggregate stability on water. Revista Brasileira de Ciência do Solo 30: 543553. (in Portuguese, with abstract in English).

Bertol, I.; Cogo, N.P.; Miquelluti, D.J. 1997. Size-distribution of eroded sediments in the runoff water as affected by residue mulch, surface roughness, and discharge rate. Pesquisa Agropecuária Gaúcha 3: 199-206. (in Portuguese, with abstract in English).

Bertol, I.; Barbosa, F.T.; Fabian, E.L.; Pegoraro, R.; Zavaschi, E.; Paz González, A.; Vidal Vázquez, E. 2008. Surface runoff in different soil management systems on typical Hapudox soil. Revista Brasileira de Engenharia Agrícola e Ambiental 12: 243250. (in Portuguese, with abstract in English).
Bertol, I.; Mello, E.L.; Cogo, N.P.; Vidal Vázquez, E.; Paz González, A. 2006. Water-erosion related parameters under steady runoffrate, in different soil tillage methods. Revista Brasileira de Ciência do Solo 30: 715-722. (in Portuguese, with abstract in English).

Bertol, I.; Zoldan Jr., W.A.; Fabian, E.L.; Zavaschi, E.; Pegoraro, R.; Paz González, A. 2008. Effect of a chiseling and rainfall erosivity on some parameters of water erosion in management systems of a typical Hapludox. Revista Brasileira de Ciência do Solo 32: 747-757. (in Portuguese, with abstract in English).

Cogo, N.P.; Moldenhauer, W.C.; Foster, G.R. 1983. Effect or crop residue, tillage-induced roughness, and runoff velocity on size distribution of eroded soil aggregates. Soil Science Society of America Journal 47: 1005-1008.

Darboux, F.; Huang, C. 2005. Does soil surface roughness increase or decrease water erosion and particle transfers? Soil Science Society of America Journal 69: 748-756.

Engel, F.L.; Bertol, I.; Ritter, S.R.; Paz González, A.; Paz-Ferreiro, J.; Vidal Vázquez, E.. 2009. Soil erosion under simulated rainfall in relation to phenological stages of soybeans and tillage methods in Lages, SC, Brazil. Soil \& Tillage Research 103: 216-221.

Gilley, J.E.; Finkner, S.C.; Varvel, G.E. 1987. Size distribution of sediment as affected by surface residue and slope length. American Society of Agricultural Engineering 30: 1419-1424.

Kamphorst, E.C.; Jetten, V.; Guèrif, J.; Pitränen, J.; Iversen, B.V.; Douglas, J.T.; Paz, A. 2000. Predicting depressional storage from soil surface roughness. Soil Science Society of America Journal 64: 1749-1758.

Leite, D.; Bertol, I.; Guadagnin, G.C.; Santos, E.J.; Ritter, S.R. 2004. Water erosion on a Hapludox submitted to different soil managements under simulated rainfall. I. Soil and water losses. Revista Brasileira de Ciência do Solo 28: 1033-1044. (in Portuguese, with abstract in English).

Lu, J.Y.; Cassol, E.A.; Moldenhauer, W.C. 1989. Sediment transport relationships for sand and silt loam soils. American Society of Agricultural Engineering 32: 1923-1931.

Panuska, J.C.; Karthikeyan, K.G.; Miller, P.S. 2008. Impact of surface roughness and crusting on particle size distribution of edge-of-field sediments. Geoderma 145: 315-324.

Paz-Ferreiro, J.: Bertol, I.: Vidal Vázquez, E. 2008. Quantification of tillage, plant cover, and cumulative rainfall effects on soil surface microrelief by statistical, geostatistical and fractal indices. Nonlinear Processes in Geophysics 15: 575-590.

Sadeghi, S.H.R.; Ghaderi V.B.; Safaeeian, N.A. 2007. Comparison between effects of open grazing and manual harvesting of cultivated summer rangelands of northern Iran on infiltration, runoff and sediment yield. Land Degradation and Development 18: 608-620.

Swanson, N.P. 1965. Rotating-boom rainfall simulator. American Society of Agricultural Engineering 8: 71-72.

Tormena, C.A.; Silva, A.P.; Imhoff, S.D.; Dexter, A.R. 2008. Quantification of the soil physical quality of a tropical Oxisol using the index. Scientia Agricola 65: 56-60.

Zoldan Júnior, W.A.; Bertol, I.; Pegoraro, R; Fabian, E.L.; Zavaschi, E.; Vidal Vázquez, E. 2008. Soil superficial roughness formed by chiseling and affected by rainfall erosivity. Revista Brasileira de Ciência do Solo 32: 353-362. (in Portuguese, with abstract in English).

Received July 08, 2008

Accepted May 04, 2010 